\title{
Distribution Process of Pesticides in Vegetable Production in the Southern Part of Bangladesh
}

\author{
Afjal Hossain ${ }^{1}$, Jafirullah Khan ${ }^{2}$, \& Mohammad Asaduzzaman Miah ${ }^{3}$ \\ ${ }^{1}$ Assistant Professor, Department of Marketing, Patuakhali Science and Technology University, Patuakhali, BANGLADESH \\ ${ }^{2}$ Assistant Professor, Department of Business Administration, Atish Dipankar University of Science and Technology, Dhaka, BANGLADESH \\ ${ }^{3}$ Assistant Professor, Department of Entomology, Patuakhali Science and Technology University, Patuakhali, BANGLADESH
}

\begin{abstract}
This study reveals the way of understanding the usages of pesticides and the development of the distribution process of pesticides in vegetable production in southern part of Bangladesh. In this regard, a descriptive study has been, at first, conducted to understand the insights about the pesticide use. A sample of 152 farmers has been interviewed from different regions of Patuakhali and Barisal districts of Bangladesh. To test the data analysis, ANOVA, KMO statistic, and also factor analysis have been conducted and the result revealed that convenient location and collection process of the pesticides are the most important factors for the farmers to produce vegetable.
\end{abstract}

Key words: ANOVA, KMO statistic, Factor analysis, Distribution process, Bangladesh

\section{INTRODUCTION}

I n Bangladesh as the colonial rulers did not obviously pay attention to the well-being of the people, food production could not keep pace with the ever increasing population. As a result, food shortages and malnutrition have become chronic problems. Malnutrition is a serious public health problem in Bangladesh. It retards child growth, increases the risk and duration of illness, reduces work output, and slows social and mental development. Nutrition survey in rural Bangladesh reports that average intake meat only $80 \%$ of calories, $58 \%$ of vitamin A, $50 \%$ of riboflavin and $51 \%$ of the vitamin requirement (BINFS 1982). Rice, the staple food, contributes more than $80 \%$ of our daily food intake. Although vegetable form an indispensable part of our daily diet, they contribute a very small percentage of total food intakes partly due to short supply, production, and health unawareness. The availability of vegetable per head per day is only $82 \mathrm{~g}$. whereas the nutritionists suggest that on an average, a person should eat at least $235 \mathrm{~g}$. of vegetable a day to maintain good health. Though the trends in vegetable production are increasing in Bangladesh in the recent period, per capita consumption of vegetable is very low (about $32 \mathrm{gm} /$ day/person) compared to neighboring countries, like in Nepal (42 g), India (135 g) and Srilanka (120 g) (Rampal and Gill 1990). Helen Keller International's (HKI) recent national vitamin A survey in rural Bangladesh showed that children from households without a home garden were at greater risk of vitamin A deficiency than children of households with a home garden. So, intensive vegetable production is needed for nutritional security, employment generation, and higher farm income, better export potential and lower depending on cereal consumption (Elias and Hussain, 1994). Therefore, the planners should refer vegetable also a staple food as rice does. So, if we can grow more vegetable, the problem of existing acute malnutrition and food shortages might be overcome to a significant extent. Under the socioeconomic condition, an improved natural farming pesticide may be used an important pesticide in improving vegetable production. The area under vegetable cultivation in Bangladesh is small. Bangladesh is facing a chronic food shortage which is now approaching 2 million mg. per year. For the last few decades, the government has been trying in vain to become self-sufficient in food production. When the planners refer to the food they mean rice only, they are not giving attention to improve the production of crops like vegetable. For the planners, the term food should also include fruits and vegetable, which are indispensable for maintaining good health. In fact, existing acute malnutrition problems could be overcome by increasing vegetable production. To meet the minimum daily requirement of vegetable, i.e. $235 \mathrm{~g}$. per head per day, we should increase vegetable production by about 7.5 million mg.-An increase of 300\% (A. R. Chowdhury, 2008).

On the other hand, Bangladesh does not produce any active ingredients which are used in vegetable production, it only imports and formulates. The marketing channel of pesticides in Bangladesh consists of pesticide companies, distributors, wholesalers, wholesaler-cum-retailers, retailers and farmers (Sabur and Moila, 2000). At the top, there exist approximately 66 
officially registered companies, with 6 of these being multinational in nature. Distributors buy almost all of their products from pesticide companies. However, the pesticide companies also directly sell to wholesalers. Distributors, in turn, sell their products to the wholesalers-cum-retailers. Retailers, in turn, sell their product to farmers, but farmers frequently buy directly from the distributors as well as wholesalers. That's why the cost of the pesticide is increasing; as a result the cost of the vegetable is also increasing. So, for the better production and distribution of the vegetable, it is necessary to implement a proper marketing process of all the inputs of the vegetable (Dasgupta, S. et al,2005).

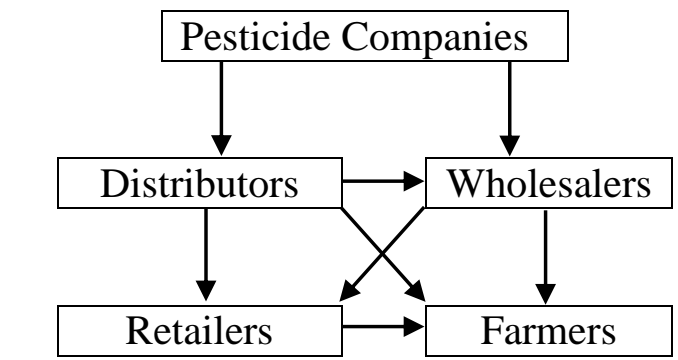

Figure 1 A Simplified Representation of Pesticide Marketing Channels in Bangladesh

Like many developing countries, Bangladesh has promoted the use of pesticides to expand agricultural land and increase output per acre. As a consequence of this expansion policy, pesticide use has more than doubled since 1992, rising from 7,350 metric tons to 16,200 metric tons in 2001. An FAO analysis of pesticide composition revealed high shares of toxic chemicals which have known to cause cancer, genetic damage, fetal damage, and severe allergic responses in exposed populations (for example, carbamates and organophosphates in insecticides, and dithiocarbamates and inorganic in fungicides) (Zahm, Ward and Blair, 1997). Many pesticides used in Bangladesh are also banned or restricted under international agreements (Meisner, 2004; NOVIB, 1993; SOS-arsenic.net, 2004; SUNS, 1998). Pesticide suppliers in Bangladesh even continue to sell the 12 particularly controversial pesticides known by activists campaigning worldwide as the "dirty-dozen" (SUNS, 1998); SOS-arsenic.net, 2004). In addition, several studies have shown that inadequate product labeling and users' lack of information have led to widespread overuse and misuse of dangerous pesticides. Anecdotal evidence suggests that the consequence of these practices is numerous, with pesticide poisonings abound (Ramaswamy, 1992).

\section{ObJectives}

To survive the people of Patuakhali District with sufficient vegetable our research has given emphasis on the following objectives:

[1] To find out why the vegetable are not produced a lot (finding the factors affecting distribution process of pesticides)

[2] To find out why they purchase vegetable from other regions

[3] To give proper direction of getting and using the proper pesticides to their vegetable

\section{Methodology}

The research was conducted by both primary and secondary data and pertinent literature survey. At first a descriptive study was conducted to understand the insights of farming the land in the purpose of vegetable production and about the pesticides collection. Then the study will conduct through a structured questionnaire with measurement scaling by considering a sample size of 152 farmers. A 5-point structured questionnaire (1: Exactly not, 2: Not, 3: Somewhat know, 4: Yes and 5: Exactly know) is developed to know the perception of the farmers about the distribution process of the pesticides to this southern part of Bangladesh. The data has been collected from the farmers of Dumki Upazilla, Galachipa Upazilla and Distributors Offices of Patuakhali District and Some regionsof Barisal district from January to December 2012. SPSS ${ }^{1}$ Software will be used to analyze the data. ANOVA and KMO statistic are done to simplify the significance of the research. The statistical tool, factor analysis $^{2}$ was conducted to identify the important factors from the responses of the 152 sample farmers regarding 8 variables which account for their inter-correlation. A principal factor analysis with an orthogonal rotation (Varimax) by using the SPSS statistical package was performed on the survey data and was used to separate the factors.

\section{Data AnALYsis}

A total 4,431.4 decimal land of different land owners of Dumki Upazilla, Galachipa Upazilla of Patuakhali District and some regions of Barisal District have been surveyed. The total production of these lands is $1,90,375.20 \mathrm{Kg}$ where the average production is $43.95 \mathrm{Kg} /$ decimal. Most of the farmers produce the vegetable only for their family consumption due to shortage of sufficient and good pesticides. Most of the pesticide distributors of these regions are retailers, but there are also some wholesalers and dealers. They mainly sell packaged pesticides with list price of the goods. Sometimes they also sell their products at discounted price. So, the farmers are only purchased their necessary pesticides from the retailers (with the) for their use of pesticides in the field. The following are the results. 
Asian Business Review, Volume 4, Number 2/2014 (Issue 8)

ISSN 2304-2613 (Print); ISSN 2305-8730 (Online)

Table 1 Distributor of Pesticides

\begin{tabular}{|l|c|c|c|c|}
\hline $\begin{array}{l}\text { Type of } \\
\text { Sellers }\end{array}$ & Frequency & Percent & $\begin{array}{c}\text { Valid } \\
\text { Percent }\end{array}$ & $\begin{array}{c}\text { Cumulative } \\
\text { Percent }\end{array}$ \\
\hline Dealer & 48 & 31.6 & 31.6 & 31.6 \\
\hline Retailer & 94 & 61.8 & 61.8 & 93.4 \\
\hline $\begin{array}{l}\text { Local } \\
\text { agricultural } \\
\text { farm }\end{array}$ & 2 & 1.3 & 1.3 & 94.7 \\
\hline $\begin{array}{l}\text { Private } \\
\text { organization }\end{array}$ & 8 & 5.3 & 5.3 & 100.0 \\
\hline Total = & 152 & 100.0 & 100.0 & \\
\hline
\end{tabular}

From Table 1 it is shown that the percentage of farmers who collect pesticides from retailers accounted for $61.80 \%$. They also purchase the pesticides from dealers, private organizations and also from local agricultural farms.

Table 2 describes the information regarding pesticides where most of the farmers collect the periodical information accounts for $69.70 \%$.

Table 2 Information regarding pesticides

\begin{tabular}{|l|c|c|c|c|}
\hline Scaling Point & Frequency & Percent & $\begin{array}{c}\text { Valid } \\
\text { Percent }\end{array}$ & $\begin{array}{c}\text { Cumulative } \\
\text { Percent }\end{array}$ \\
\hline Sometimes Know & 38 & 25.0 & 25.0 & 25.0 \\
\hline Yes (All the time) & 8 & 5.3 & 5.3 & 30.3 \\
\hline Periodically know & 106 & 69.7 & 69.7 & 100.0 \\
\hline Total = & 152 & 100.0 & 100.0 & \\
\hline
\end{tabular}

Table 3 illustrates the collection process of the pesticide where 17 farmers didn't make any comment. About $86 \%$ of the total farmers said that their make their payment in the face value of the pesticide. Also there are some farmers who collect the pesticide through down payment and discounted price.

Table 3 Collection Process

\begin{tabular}{|l|c|c|c|c|}
\hline Price & Frequency & Percent & $\begin{array}{c}\text { Valid } \\
\text { Percent }\end{array}$ & $\begin{array}{c}\text { Cumulative } \\
\text { Percent }\end{array}$ \\
\hline Book Value & 130 & 85.5 & 96.3 & 96.3 \\
\hline Discounted Price & 4 & 2.6 & 3.0 & 99.3 \\
\hline $\begin{array}{l}\text { Down payment } \\
\text { price }\end{array}$ & 1 & .7 & .7 & 100.0 \\
\hline Total & 135 & 88.8 & 100.0 & \\
\hline Missing & 17 & 11.2 & & \\
\hline Total= & 152 & 100.0 & & \\
\hline
\end{tabular}

Table 4 Type of Pesticides

\begin{tabular}{|l|c|c|c|c|}
\hline Type of Pesticides & Frequency & Percent & $\begin{array}{c}\text { Valid } \\
\text { Percent }\end{array}$ & $\begin{array}{c}\text { Cumulative } \\
\text { Percent }\end{array}$ \\
\hline $\begin{array}{l}\text { Non-packaged } \\
\text { pesticides }\end{array}$ & 6 & 3.9 & 4.4 & 4.4 \\
\hline Packaged pesticides & 130 & 85.5 & 95.6 & 100.0 \\
\hline Total & 136 & 89.5 & 100.0 & \\
\hline Missing & 16 & 10.5 & & \\
\hline Total = & 152 & 100.0 & & \\
\hline
\end{tabular}

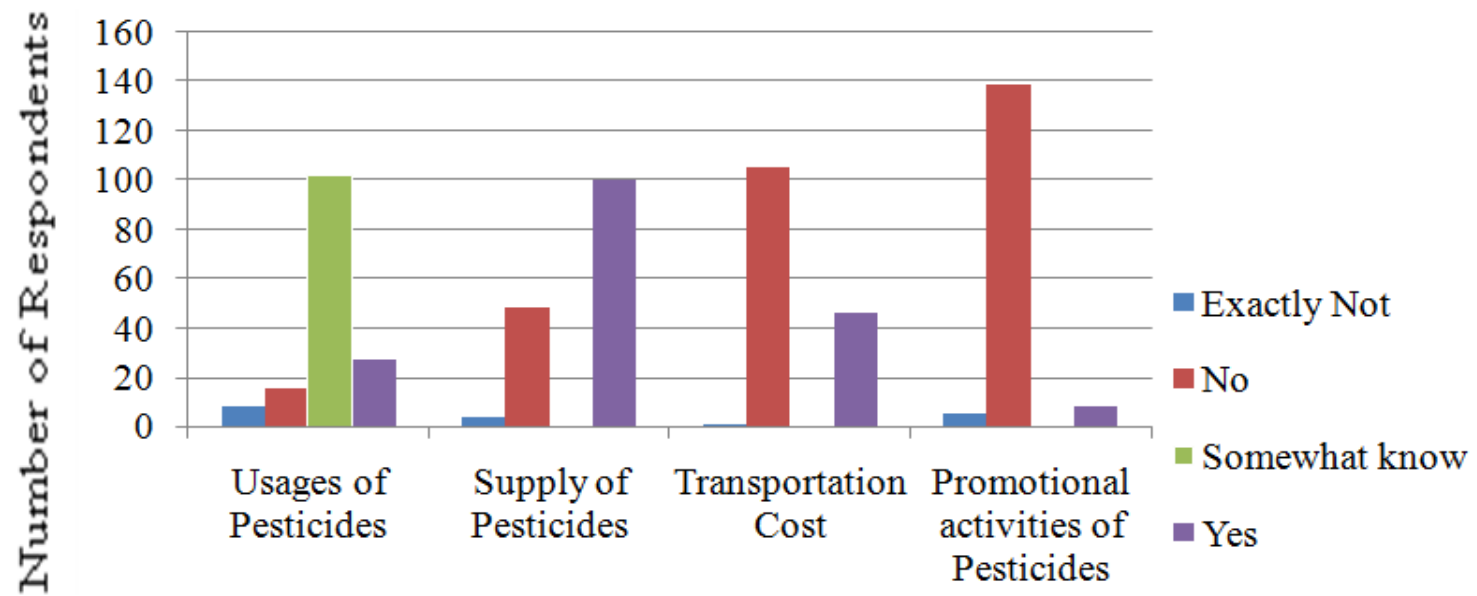

Figure 5 Usages, Supply, Transportation Cost and Promotional activities of Pesticides

Table 5 shows the 5 relative factors associated with the pesticide distribution process to the southern part of Bangladesh. It is shown that the farmers do not exactly know about the usages of the pesticide to their vegetable field. They only somewhat know about their previous farming experience of their field. Out of 152 respondents only 100 farmers said that the pesticides are supplied properly to their hand. But about $32 \%$ farmers said that they are not properly supplied. In case of transportation cost, almost 30\% of total respondents said that they have to pay the transportation cost for the collection of the pesticides. In case of $91 \%$ of the total respondents said that there are no promotional activities for their pesticides selling. The research is tested in Table 6 and Table 7.

Table 6 ANOVA Test

\begin{tabular}{|l|l|l|l|l|l|l|}
\hline Model & & $\begin{array}{l}\text { Sum of } \\
\text { Squares }\end{array}$ & Df & $\begin{array}{l}\text { Mean } \\
\text { Square }\end{array}$ & F & Sig. \\
\hline \multirow{3}{*}{1} & Regression & 7.930 & 7 & 1.133 & 2.218 & $.037(\mathrm{a})$ \\
\cline { 2 - 7 } & Residual & 61.791 & 121 & .511 & & \\
\cline { 2 - 7 } & Total & 69.721 & 128 & & & \\
\hline
\end{tabular}

a Predictors: (Constant), Type of Pesticides, Promotional activities of pesticides, Supply of Pesticides, Information regarding Pesticides, Distributor of Pesticides, Transportation Cost, Collection Process 
From ANOVA Test, it shows that the table sig. value 0.05 is greater than the calculated sig. value 0.037 . So, it rejects the null hypothesis at $5 \%$ level of significance. It means there was a significant correlation between dependent variable and independent variables. Therefore, usages of pesticides depend on the distribution process of pesticides to the different region in the southern part of Bangladesh.

Table 7 KMO and Bartlett's Test

\begin{tabular}{|l|l|l|}
\hline Kaiser-Meyer-Olkin & .509 \\
Measure of Sampling Adequacy. & \\
\hline $\begin{array}{l}\text { Bartlett's Test } \\
\text { of Sphericity }\end{array}$ & Approx. Chi-Square & 67.348 \\
\cline { 2 - 3 } & Df & 28 \\
\cline { 2 - 3 } & Sig. & .000 \\
\hline
\end{tabular}

The factor analysis shows that the three factors with egenvalue4 greater than one (Table 1). These three factors are identified out of 8 variables explain about 53\% variability of the data. The factor analysis of 8 variables with 152 sample is found adequate (KMO test result $=0.509>0.50$ ) and valid (Bartlett's test of sphericity indicates a significance level of 0.000). The communalities of the variables that constituted the factors are found very strong which indicates robust relationships among the variables (Appendix 1).

Table 8 Eigen value, Relative Variance (\%) and Cumulative Relative Variance (\%) of the Factors

\begin{tabular}{|l|l|l|l|l|}
\hline Factors & Factor Name & $\begin{array}{l}\text { Eigen } \\
\text { value }\end{array}$ & $\begin{array}{l}\% \text { of } \\
\text { Variance }\end{array}$ & $\begin{array}{l}\text { Cumula } \\
\text { tive } \%\end{array}$ \\
\hline 1 & Convenience & 1.611 & 20.143 & 20.143 \\
\hline 2 & Motivation & 1.508 & 18.848 & 38.992 \\
\hline 3 & Demand and Supply & 1.123 & 14.036 & 53.027 \\
\hline
\end{tabular}

Extraction Method: Principal Component Analysis

Also it can be noted that the first factor (Convenient) appears to be the most important as it explains $20.143 \%\left(\sigma^{2}\right)$ of the variability. Other factors are Motivation $\left(\sigma^{2}=18.848 \%\right)$ and Friendly $\left(\sigma^{2}=14.036 \%\right)$.

Table 9.Component Matrix (a)

\begin{tabular}{|l|r|r|r|}
\hline \multicolumn{1}{|c}{ Variables } & \multicolumn{1}{c|}{ Factor } & \multicolumn{2}{c|}{} \\
\cline { 2 - 4 } & \multicolumn{1}{c|}{ First } & \multicolumn{1}{c|}{ Second } & \multicolumn{1}{c|}{ Third } \\
\hline Distributor of Pesticides & .703 & -.121 & -.093 \\
\hline $\begin{array}{l}\text { Information regarding } \\
\text { Pesticides }\end{array}$ & .143 & -.642 & .248 \\
\hline Usages of Pesticides & -.499 & -.288 & .433 \\
\hline Supply of Pesticides & -.111 & .328 & .544 \\
\hline Transportation cost & -.359 & .607 & .079 \\
\hline $\begin{array}{l}\text { Promotional activities of } \\
\text { pesticides }\end{array}$ & .284 & .644 & .292 \\
\hline Collection Process & .742 & .228 & .087 \\
\hline Type of Pesticides & -.275 & .236 & -.685 \\
\hline
\end{tabular}

Extraction Method: Principal Component Analysis 3 components extracted

\section{FIRST FACTOR: CONVENIENCE}

It appears that convenient location is the most important factor in the eyes of respondents (farmers) for the pesticides collection of their vegetable production. Based on their responses it may be deducted that the respondents believe that distributor of the pesticides location and collection process are the important two variables (Table 4). Both of the variables have factor loading of more than 0.50 . This clearly shows the relative strength of these individual variables. Therefore, presence of convenient location of the pesticides outlets is very important factor for two reasons: (a) They have the highest factor loadings and (b) It saves the transportation cost and time too.

\begin{tabular}{|l|l|l|}
\hline S.N & Name of the variables & $\begin{array}{l}\text { Name of } \\
\text { the Factor }\end{array}$ \\
\hline 1 & $\begin{array}{l}\text { Distributor of Pesticides, Collection } \\
\text { Process }\end{array}$ & Convenience \\
\hline 2 & $\begin{array}{l}\text { Transportation cost, Promotional } \\
\text { activities of pesticides, Type of } \\
\text { Pesticides }\end{array}$ & Motivation \\
\hline 3 & $\begin{array}{l}\text { Information regarding Pesticides, } \\
\text { Usages of Pesticides, Supply of } \\
\text { Pesticides }\end{array}$ & $\begin{array}{l}\text { Demand and } \\
\text { Supply }\end{array}$ \\
\hline
\end{tabular}

\section{SECOND FACTOR: MOTIVATION}

The second most important factor is motivation to the farmers for the pesticides marketing in southern part of Bangladesh for their vegetable production. The variables (Transportation cost, promotional activities of pesticides and types of pesticides) under this factor also have a relatively high factor loading of more than 0.50 . The presence of motivation of the farmers about pesticides leads the proper usages and purchases the pesticides in the proper time.

\section{THIRD FACTOR: DEMAND AND SUPPLY}

The last important factor in the eyes of the respondents (farmers) for the pesticide collection of their vegetable production is demand and supply of pesticide. Two of the variables under this factor have less factor loadings (less than 0.050) are: information regarding pesticides, usages of pesticides.The only supply of pesticides variable has more factor loadings (more than 0.50). This means the supplier of the pesticides can consider this factor, but if they do then it will be better for the company as well as the farmers to use in their vegetable field.

\section{Conclusion AND ReCommendation}

Bangladesh is a developing country of which most of poor people are living in the southern part of Bangladesh. The income levels of these people are very small amount that's why they didn't use the necessary things in the proper time. They are just living from hand to mouth. Even they just produce the products in their daily lives with raw pesticides and fertilizers. Even they purchased the daily 
goods which come from the other regions because of the lower price rather than their own produced goods because of charging a higher cost. So, if the distribution process of pesticides are not well developed then it is impossible to good to these people. The following recommendations are made for the development of the proper distribution process of the pesticides:

- One cost-effective approach would be to increase awareness and training at the wholesaler or retailer level, where the effort has its greater reach to make understanding of the farmers about the usages of the pesticides.

- The outlets of pesticides should be in a convenient location because of the easy collection process of the pesticides. It will also reduce the total production cost of the vegetable.

- There should be promotional activities for the pesticides. It will help the farmers more interested to purchase the pesticides and to use in their vegetable field which will increase the total production of the vegetable.

E There are not sufficient markets in their convenient location for which they have to sell their goods to the middleman; as a result they deprived from the actual profit. So, if the government can take the necessary steps regarding this issue, then the farmers will also grow their interest to produce more vegetable in their fields.

- The different media (broadcasting channels) should broadcast the issue of the pesticides usages (amount of pesticides per decimal).

- Most of the pesticides buyers are the poor buyers. So, if there is a chance to return theflawedand unused pesticides, then the farmers would be more beneficial in some context.

- The distribution process of the pesticides should be directed from the organizational distributors to the farmers so that the farmers can get the pesticides in fair price.

\section{NOTES}

E SPSS refers to the Statistical Package for Social Sciences.

- Factor analysis is a type of analysis used to discern the underlying dimensions or regularity in phenomenon. Its general purpose is to summarize the information contained in a large number of variables into a smaller number of factors. It is an interdependence technique in which all variables are simultaneously considered.

\section{APPENDIX}

\section{Appendix 1}

Factors related to the distribution process of the Pesticides marketing and their Communalities

\begin{tabular}{|l|l|l|}
\hline $\begin{array}{l}\text { Variable } \\
\text { Code }\end{array}$ & Variable Name & Extraction \\
\hline V1 & Distributor of Pesticides & .518 \\
\hline V2 & Information regarding Pesticides & .494 \\
\hline V3 & Usages of Pesticides & .519 \\
\hline V4 & Supply of Pesticides & .417 \\
\hline V5 & Transportation cost & .503 \\
\hline V6 & Promotional activities of pesticides & .581 \\
\hline V7 & Collection Process & .610 \\
\hline V8 & Type of Pesticides & .600 \\
\hline
\end{tabular}

Extraction Method: Principal Component Analysis.

\section{REFERENCES}

R. Chowdhury. 2008. Nature Farming and Vegetable Production in Bangladesh. Institute of Postgraduate Studies in Agriculture, Gazipur, Bangladesh. http://www.infrc.or.jp/english/KNF_Data_Base_Web/P DF\%20KNF\%20Conf\%20Data/C1-3-008.pdf.

BINFS (1981-82) Bangladesh Institute of Nutrition and Food Science: Nutrition Survey of Rural Bangladesh 1981-82, University of Dhaka, Bangladesh.

Dasgupta, S. et al.2005.Agriculture \& Rural Development. Report No. WPS3777. http://wwwwds.worldbank.org/external/default/WDSContentServer/I W3P/IB/2005/11/18/000016406_20051118151856/Rendered /PDF/wps3777.pdf. Accessed Date: March 20, 2013

Elias SM, Hussain MS (1994) Agricultural Economics Research on vegetable in Bangladesh.Workshop on vegetable production system and consumption pattern in South and South East Asia. Bangkok, Thailand, October 1994.

Helen Keller International.March-April 1994-October-December, 1996. NGO Gardening and Nutrition Education Surveillance Project (NGNESP): Monitoring of Activities in the Village Nurseries and Household Gardens, Report 1-9, HKI, Dhaka.

Meisner, C. (2004), 'Report of Pesticide Hotspots in Bangladesh', Report to the Canadian International Development Agency (CIDA). Mimeo. Washington DC: World Bank.

NOVIB (1993), 'Pesticides Misuse in Bangladesh', The Pesticides News, No. 22, Dec. 1993. The Pesticides Trust. London, U.K.

Ramaswamy, S. (1992), 'Pest Control and Environment', Notes for discussion at a seminar on environment and agriculture. Agriculturalist Association of Bangladesh, Dhaka, p. 19.

Rampal, Gill HS (1990) Demand and supply of vegetable and pulses and in vegetable Research and Development in South Asia. Proceeding of a workshop held at Islamabad, Pakistan, 24-29 September, 1999.

Sabur, S.A. and A. R. Molla. 2000. Marketing and Economic Use of Pesticides: Impact on Crop Production. Bangladesh Agricultural University, Mymensingh, Bangladesh (mimeo).

SOS-Arsenic.net (2004), 'Agrochemicals: Imported Pollutants in Bangladesh', Available at: http://www.sosarsenic.net/index.html.

SUNS (1998), 'Pesticide Overuse Takes Serious Turn in Bangladesh', Monday, Jan. 24, (Dhaka, Jan. 23 IPS/Tabibul Islam).

Zahm, S. H., M. H. Ward and A. Blair (1997), 'Pesticides and Cancer', in M. Keifer, ed., Occupational Medicine: State of the Art Reviews, Vol. 12: Pesticides, Philadelphia: Hanley and Belfus, Inc., 269-289.

--0-- 